\title{
The relationship between human resource management practices and organisational citizenship behaviour
}

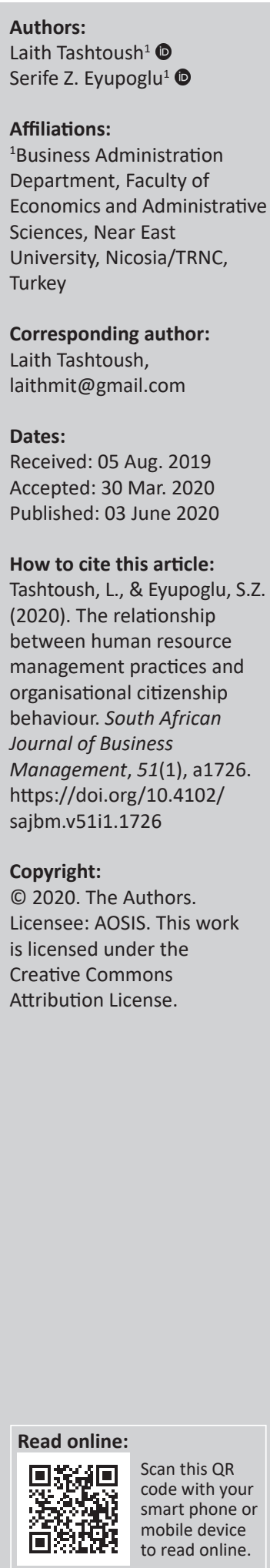

Purpose: This study aims at providing empirical evidence on the extent to which organisational commitment mediates and strengthens the relationship between human resource management practices and organisational citizenship behaviour amongst administrative staff working in Jordanian universities.

Design/methodology/approach: Data were gathered using a questionnaire. The population of the study consisted of administrative staff working at 29 universities. A total of 350 employees participated in the study. Data analysis involved the computation of descriptive statistics, as well as structural equation modelling, factor analysis, regression and correlation analysis.

Finding/results: The results of the study indicated that the human resource management practices, organisational commitment, and organisational citizenship behaviour were statistically significant. Moreover, it was found that human resource management practices through organisational commitment impact organisational citizenship behaviour.

Practical implication: The literature supports that organisational citizenship behaviour promotes the effective functioning of any organisation as well as contributing to the overall success of the organisations. Therefore, there is a need to conduct studies that concentrate on how to improve organisational citizenship behaviour so that organisations can sustain performance.

Originality/value: The conceptual model developed in this study provides relationships of human resource management practices through organisational commitment that can be used by the management of organisations as a guide to positively influence the organisational citizenship behaviour of the employees in their organisations.

Keywords: organisational citizenship behaviour, human resource management practices, organisational commitment, administrative staff, universities, Jordan.

\section{Introduction}

Human resources management (HRM) experienced significant changes during the 20th century (Deadrick \& Stone, 2014). Human resources management emphasises various issues, including the harmonisation of HRM practices with strategic organisational objectives to develop the process of employees' recruitment and selection (RS), compensation system (CS) and performance appraisal (PA) to fulfil organisational goals (Millmore, Lewis, Saunders, Thornhill, \& Morrow, 2007). Huang (2001) believed that HRM focuses on the behavioural aspects of employees and how they affect the performance of the organisation. Thus, to have control over HRM practices, Liao (2005) suggested that an organisation's strategy should reinforce employees' behaviours that could benefit the organisation for a certain period.

Organisational citizenship behaviour (OCB) refers to what the employees choose to do on their own, which often lies outside of their job description and their contract (Organ, 1990). Roos, Fernstroom and Pike (2004) argued that OCB promotes the effective functioning of organisations, meaning that high levels of OCB create situations in which employees have a special interest, willingly comply with rules and regulations that maintain the organisation's operations and exceed formal requirements or expectations, all of which contribute to the success of the organisation.

Organisational commitment (OC) is considered to be one of the most documented antecedents of OCB, which clarifies the connection between the employees and the organisation (Meyer, Stanley, Herscovitch, \& Topolnytsky, 2002). Saraih et al. (2017) suggested that OC is also important in 
testing an employee's commitment within an organisation. When employees are committed to their work, this can reinforce other behavioural factors such as OCB. The researchers have also stressed that some employees may not only be volunteers because they are already willing to act, but because OC drives them to help their peers when they believe the organisation treats them fairly because of this behaviour (Friedman, Carmeli, \& Dutton, 2018; Graso, Camps, Strah, \& Brebels, 2019). The significance of studying OC in this context is connected to behavioural orientation when there is little anticipation of formal organisational pay-off for performance (Claudia, 2018). Therefore, researchers within the HRM field are starting to recognise the relevance of OC and OCB for their endeavours, and studies linking the two are now beginning to emerge (Matsuyama, 2006; Suifan, 2015).

Over the past few decades, there has been increased interest in HRM in the field of higher education because of the recognition that higher educational institutions require intensive labour, allocate their budgets to the employees and often rely on their administrative staff (Küskü, 2003). Higher education institutions seek to achieve greater organisational effectiveness despite the considerable competition for resources on which they rely, especially human resources. Organisational citizenship behaviour can enhance organisational effectiveness to the extent that it improves joint work and increases administrative productivity, which in turn reduces the need to devote scarce resources to jobs and acts as an effective means of coordinating activities between team members and across groups (Holeche, 2017). Organisational citizenship behaviour also has the potential to enhance higher education's institutions' capacity to recruit and retain competent candidates and to enhance organisational stability, which reinforces the OC of the employees (Organ, Podsakoff, \& MacKenzie, 2006).

Administrative staff working at universities is an essential element of the organisational structure. Without their support, universities cannot serve the community or perform their educational, research-related activities. In areas of student affairs, admission and registration, finance, public relations, personnel, maintenance, services, security and other administrative functions, the work cannot be completed without administrative staff. Because administrative staff members are responsible for the provision of administrative as well as educational services, universities are required to provide them with an appropriate organisational environment to work well, which enhances their commitment to their university and encourages them to achieve the goals that were created for them. Few studies exist in relation to academic and administrative staff working at Jordanian universities (Al-Mzary, Al-rifai, \& Al-Momany, 2015; Al-Saudi, 2012; Qawasmeh, 2018). However, research on HRM, OCB and OC amongst administrative staff working in educational institutions is not apparent in the literature and this represents a significant gap. Therefore, this study contributes by empirically examining this relationship amongst administrative staff working at Jordanian universities.

\section{Theoretical framework and hypotheses development}

\section{Human resources management practices and organisational commitment}

Universities should implement practices aimed at improving HRM because it is a vital component of an organisation's endurance. Sial et al. (2011) conducted a study on many universities' faculty members in Pakistan and found that HRM practices that had been applied effectively led to increased levels of OC amongst employees. Savaneviciene and Stankeviciute (2011) suggested that OC can be improved by increasing HRM practices. Whitener (2001) showed that PA, CS and training and development (TD) are major variables in reinforcing OC. Hassan and Mahmood (2016) conducted a study in different sectors in Pakistan and pointed out that OC arises from the extent of employee satisfaction with HRM practices. Also, Nasurdin, Hemdi and Lye (2008) suggested that employee's perceptions of the HRM practices performed by their organisations served as a direct predictor of their commitment. Sung and Choi (2014) reported that the higher level of OC in an organisation is a result of the effective implementation of its HRM practices. Hoon and Heard (2000) considered that employee behaviour such as $\mathrm{OC}$ is the consequence of the effort of HRM practices and they suggested that one of the objectives of HRM practices should be to increase the levels of OC amongst employees. Therefore, HRM practices can be considered as an effective tool for OC enhancement. Based on the above discussion, the following hypothesis is proposed:

H1: Human resource management practices positively influence organisational commitment.

\section{Organisational commitment and organisational citizenship behaviour}

Meyer et al. (2002) conducted an empirical study describing the impact of regulatory compliance components on OCB. They found that affective commitment (AC) was associated with OCB, whilst ongoing commitment had no relationship with OCB. Morrison (1996) noted that amongst the OC elements, the most critical is AC. Conversely, the study of Kuehn and Al-Busaidi (2002) found that the most significant variables for OCB were job satisfaction and normative commitment. Other empirical studies have shown a statistically significant relationship between OC and OCB (Hartono \& Handayani, 2019; Suparjo \& Darmanto, 2015; Yanti \& Supartha, 2017). Liu, Loi and Ngo (2018) said that OC is predictive of OCB because it has a significant impact on it. Scholl (1981) and Wiener (1982) suggested models of OC supporting the relationships between OC and OCB. Jaros (1997) stressed that highly committed employees are more likely to engage in OCB activities. MacKenzie, Podsakoff and Ahearne (2006) confirmed that OC is an important variable in explaining employees' OCB. Schappe (1998) conducted a study amongst 150 employees of a Mid-Atlantic insurance company and found that when job satisfaction and equality are taken into consideration simultaneously, only OC had a 
significant relationship to OCB. Suparjo and Darmanto (2015) conducted a study on tenured faculty members at a private university in Central Java province. The results of their study proved that $\mathrm{OC}$ is an important determinant of OCB. The results of a study carried out by Hartono and Handayani (2019) with 51 participants at AUTO2000 yielded that OC has a positive and significant impact on OCB. Therefore, the following hypothesis is proposed:

H2: Organisational commitment positively influences organisational citizenship behaviour.

\section{The mediating role of organisational commitment with human resources management practices and organisational citizenship behaviour}

Paul and Anantharaman (2004) showed that the HRM practices of software professionals had a significant positive relationship with OC. Payne and Huffman (2005) found that OC mediates the relationship between the routing of HRM practices in the organisation and the turnover of employees' overtime. Wright, Gardner and Moynihan (2003) conducted a study on 50 work units in a catering company and found a significant relationship between HRM practices and OC. They also suggested that the first impact of HRM practices on OC started with RS. When universities invest in choosing the most skilled employees and provide them with increased skills through TD opportunities, the employees find the workplace full of well-qualified peers. Additionally, universities should use proper PA and CSs to provide suitable working environment where employees feel that they will be rewarded fairly and equitably in recognition of their efforts. Zheng, Zhang and Li (2012) examined how frequent employee evaluations determined OCB and concluded that this relationship occurred only when OC acted as a mediator variable. Previous research on HRM practices, OC and OCB has been conducted on employees in the administration and banking areas, in medical clinics and schools (Grawe, Daugherty, \& McElroy, 2012; Stamper \& Dyne, 2014). In this respect, the following hypothesis is proposed:

H3a: Organisational commitment mediates the relationship between human resource management practices and organisational citizenship behaviour.

\section{Recruitment and selection}

Recruitment is the process of creating a group of qualified applicants to apply for positions within an organisation, whereas selection refers to the process of specific tools used to choose from a group of persons who are the most suitable for the job (Bratton \& Gold, 2017). Cho, Woods, Jang and Erdem (2006) examined pre-employment examination as a primary factor of RS and found that applicants who passed the examination might develop a stronger sense of belonging and when applied these tests help select employees who stay with the organisation longer because they have a sense of belonging in the organisation. As a result, there is an increase in the degrees of OC. Bettencourt, Gwinner and
Meuter (2001) suggested that OCB will likely emerge if employees acquire a positive image of their organisation at the onset of their employment. In other words, when organisations implement an effective RS process, their employees will have a higher level of OC. Guyo (2015) suggested that employees may be more willing to get citizenship than others. Moreover, HR managers could target applicants who generally tend to participate in OCB. Therefore, the following hypothesis is proposed:

H3b: Organisational commitment mediates the relationship between recruitment and selection and organisational citizenship behaviour.

\section{Compensation system}

Sung, Choi and Kang (2017) suggested that CS functioned as a remarkable driver of the positive attitude and behaviour of employees that increases organisational operations and effectiveness, which, in turn, enhances employee commitment and competence and improves the operational and financial performance of the organisation. The studies carried out by a group of researchers (Angelina \& Subudi, 2014; Danendra \& Mujiati Ni Wayan, 2016; Makau, Nzulwa, \& Wabala, 2017) stated that compensation has a positive and significant influence on OCB, which means that if the employees perceive their salaries and benefits to be fair and if they feel that the facilities in their working environment are adequate, their OCB will also increase. Moreover, research conducted by Yanti and Supartha (2017) on the influence of OC on OCB suggested that employee commitment has a significant impact on OCB. They believed that OC can increase the awareness of the employees to do their work and develop their creative abilities to obtain more incentives and thus increase their level of OCB. Suryani, Gama and Parwita (2019) suggested that CS and OC as the leading factors that influence the OCB of employees. They proposed that the higher CS received and the higher OC of employees would lead to the higher level of OCB owned. Based on their results, they stated that CS and OC simultaneously affect OCB. Therefore, the following hypothesis is proposed:

H3c: Organisational commitment mediates the relationship between compensation system and organisational citizenship behaviour.

\section{Training and development}

Organisations with higher levels of equitable access to TD programmes are likely to increase employee's commitment towards their organisation, which, in turn, enhances their OCB (Bartlett \& Kang, 2004). Noor (2009) conducted a study on 134 Pakistani university teachers and found that TD opportunities had a significant positive correlation with OC and enhanced OCB. The TD of employees is recognised as an essential part of HRM practices usually thought to be a distinctive category of human investment capital for human and organisational improvements (Wentland, 2003). Dysvik and Kuvaas (2008) determined that when employees are provided with TD opportunities, this may result in employee commitment, which it appeared through their voluntary 
behaviours to offer an effective OCB. Recently, Alvi, Zarish and Bilal (2016) investigated the impact of TD on employees working in two different companies based in Pakistan and the effects it had on OC and OCB. They found that employee training is a good indicator of $\mathrm{OC}$ and $\mathrm{OCB}$, but employee training is the better precedent for OC compared to OCB. Ahmad (2011) has shown that support for TD is associated with OCB. Similarly, Liu (2006) proposed that TD demonstrated significant association with OC. Dockel, Basson and Coetzee (2012) revealed a significant association between TD and OCB and said that OC completely mediates the relationship between the two variables. Therefore, the following hypothesis is proposed:

H3d: Organisational commitment mediates the relationship between training and development and organisational citizenship behaviour.

\section{Performance appraisal}

Pettijohn, Pettijohn and D'Amico (2001) performed a study on retail sales employees in the United States. They stated that if there is a clear and transparent PA system within an organisation, it will lead to a high degree of OC because it enhances the perceptions of integrity amongst employees. Jawahar (2006) indicated that some other factors increase job satisfaction and $O C$, and decrease turnover intention. In her investigation, Jawahar (2006) revealed that satisfaction with the performance reactions and employees involved in the PA process is positively correlated with job satisfaction and the types of OC, whilst it is negatively correlated with turnover intention. A study by Farndale, Hope-Hailey and Kelliher (2011) supported the conclusion that the employee's knowledge of PA is the main variable that determines the level of staff commitment and demonstrates their commitment to their organisation. Hai and Mian (2007) indicated that PA, including system and process facets, significantly affects OC and plays a mediating role between PA and employees' behaviour. Hai and Mian (2007) assumed that some variables may play a mediating role, such as OC, which is a stable psychological link connecting some employees to the organisation. Zheng et al. (2012) suggested that $\mathrm{OC}$ has the mechanism of social exchange amongst PA and OCB because employees' perceptions of fairness, organisational support and their own growth which they can follow through the PA process are all related to employees' inferences of their OC to them, which are reflected in their commitment to their organisations. Empirically, OC has been found to be related to OCB (Meyer et al., 2002). Also, NorrisWatts and Levy (2004) pointed out that OC mediates the relationship between PA and OCB. In this respect, the following hypothesis is proposed:

H3e: Organisational commitment mediates the relationship between performance appraisal and organisational citizenship behaviour.

The theory of social exchange assumes that employees are committed to paying back their institutions' support and doing their utmost to achieve the results that their organisations want (Park \& Searcy, 2012). In this sense, HRM,

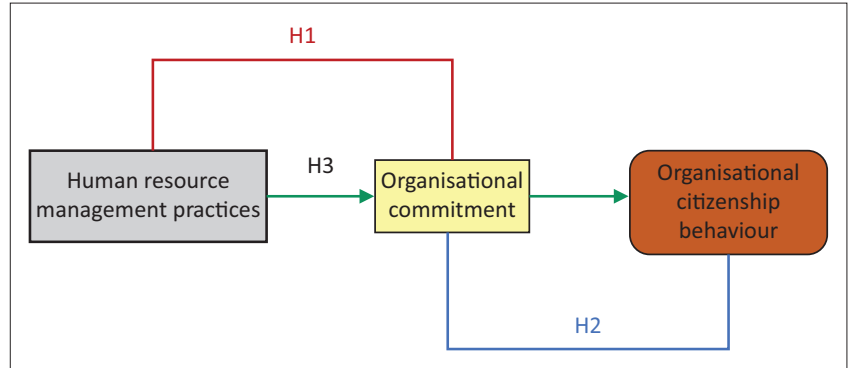

FIGURE 1: Conceptual framework of the study.

OC and OCB are variables that support each other. Effective HRM practices will increase employees' positive attitudes towards their organisation and will in turn reflect as OC and OCB. Employees will place the benefits of their organisation's above their own interests. Figure 1 illustrates the conceptual model of this study.

\section{Methodology Study variables and instrument}

The model of the research is quantitative and cross-sectional. The questionnaire consists of four parts and 71 items in total: demographic information, the Human Resource Management Scale (HRMS), the Organisational Citizenship Behaviour Scale (OCBS) and the Organisational Commitment Scale (OCS). The demographic questions consist of six items (items 1-6). The HRMS used in this study was developed by Khatri (2000), Tsaur and Lin (2004) and Atteya (2012). This scale consists of 36 items, with the format of a typical five-point Likert scale ranging from 1 (strongly disagree) to 5 (strongly agree), which divided into four sub-dimensions - RS, CS, TD and PA - with a Cronbach's alpha score of 0.850. Recruitment and selection is measured through 10 items (items 7-16), with a Cronbach's alpha score of 0.767 . Compensation system is measured through nine items (items 17-25), with a Cronbach's alpha score of 0.949 . Training and development is measured through nine items (items 26-34), with a Cronbach's alpha score of 0.740 . Performance appraisal is measured through eight items (items 35-42), with a Cronbach's alpha score of 0.766. According to Hair, Black, Babin and Anderson (2014), the level of Cronbach's alpha that needs to achieve the reliability and to be an acceptable study is 0.7 . Therefore, the Cronbach's alpha scores for the HRM practices variables for this study are reliable. Some sample questions from the HRMS are as follows: 'the university recruits individuals who have sufficient skills and experience in the planning, organisation and control of important administrative positions'.

The OCS used in this study was developed by Porter, Steers, Mowday and Boulian (1974) and Atteya (2012). This scale consists of 10 items (İtems 43-52), with the format of a typical five-point Likert scale ranging from 1 (strongly disagree) to 5 (strongly agree). The Cronbach's alpha value for the OCS was calculated as 0.777 . As with the HRMS and OCBS, this value is also considered to be reliable. Some sample questions from the OCS are as follows: 'I can get ahead in this university if I make the effort'. 
The OCBS used in this study was developed by Atteya (2012). This scale consists of 19 items (items 53-71), with the format of a typical five-point Likert scale ranging from 1 (strongly disagree) to 5 (strongly agree). The Cronbach's alpha value for the OCBS was calculated as 0.820. This value is also considered to be reliable. Some sample questions from the OCBS are as follows: 'I am willing to give my time to help my colleagues who have work-related problems'. The Cronbach's alpha value for the present study of 65 items was calculated as 0.825 , which was considered to be reliable.

\section{Sample and procedure}

The study population consisted of full-time administrative staff working at Jordanian universities. According to the statistical report of the Ministry of Higher Education and Scientific Research in Jordan for the period 2016-2017, the total population of administrative staff working at the 29 Jordanian universities was 19505 . According to Sekaran and Bougie (2016), a sample size of 377 is suitable for a population of 20 000. Consequently, a total of 377 employees were randomly selected to take part in the study by using a convenience sampling method. A questionnaire with a cover letter explaining the nature of the study was distributed by hand in different work areas within the universities, such as a research centre, administrative centres, departments, units and so on. Of the 377 questionnaires distributed, 350 usable questionnaires were returned, thereby yielding a response rate of $94 \%$. The data were collected between November 2018 and January 2019. This study was designed to meet the ethical principles of voluntary participation, ensuring that participants were not harmed, respecting their right to privacy, anonymity and self-determination. During this study, participants were informed about the importance of the study and its purpose. That is, it was mentioned that the study aimed to serve the Jordanian universities by identifying the issues of the suspected low level of OCB within universities. Also, the study would help universities to develop and design a strategic system to influence their employees' behaviour and emotions towards their work and thus influence their commitment to the university. Moreover, it was indicated that participation in the study was voluntary and the data collected during this study would be used for academic research purposes only and will be treated with strict confidentiality. Finally, the information of participants would be kept confidential and anonymous.

\section{Ethical consideration}

Ethical approval to conduct the study was obtained from the Scientific Research Ethics Committee of the Near East University (NEU/ SB/2018/281).

\section{Result \\ Demographic characteristics of respondents}

Demographic characteristics of the respondents in this study include four different aspects: gender, age, educational level and years of experience in the university. Table 1 summarises
TABLE 1: Demographical characteristics of respondents.

\begin{tabular}{|c|c|c|}
\hline Variables & Frequency & $\%$ \\
\hline \multicolumn{3}{|l|}{ Gender } \\
\hline Male & 247 & 71 \\
\hline Female & 103 & 29 \\
\hline Total & 350 & 100 \\
\hline \multicolumn{3}{|l|}{ Age (years) } \\
\hline $25-29$ & 43 & 12 \\
\hline $30-34$ & 129 & 37 \\
\hline $35-39$ & 88 & 25 \\
\hline $40-44$ & 37 & 10 \\
\hline $45-49$ & 30 & 9 \\
\hline 50 years and more than 50 years & 23 & 7 \\
\hline Total & 350 & 100 \\
\hline \multicolumn{3}{|l|}{ Educational level } \\
\hline Undergraduate & 307 & 88 \\
\hline Postgraduate & 43 & 12 \\
\hline Total & 350 & 100 \\
\hline \multicolumn{3}{|c|}{ Years of experience in this university } \\
\hline $1-4$ & 41 & 12 \\
\hline $5-9$ & 136 & 39 \\
\hline 10-14 & 95 & 27 \\
\hline 15-19 & 40 & 11 \\
\hline $20-24$ & 6 & 2 \\
\hline 25 years and more than 25 years & 32 & 9 \\
\hline Total & 350 & 100 \\
\hline
\end{tabular}

the demographic characteristics of respondents. The study results show that $71 \%$ were men, $37 \%$ were between the ages of 30 and 34 years, $88 \%$ had earned an undergraduate degree, $39 \%$ had 5-9 years of experience in the university.

\section{Factor analysis}

Exploratory factor analysis (EFA) enables the researchers to reduce the observed variables to smaller numbers and identify the relationship between them (Hinkin, 1998). The principal components analysis (PCA) technique following the Promax with Kaiser normalisation rotation method was used to extract the factors. As proposed by Hair et al. (2014), only those items that loaded 0.4 or above on a single item were included. The Kaiser-Meyer-Olkin (KMO) was 0.799 and Bartlett's test was significant at $p<0.05$, which effectively complies with Kaiser (1974) regarding the required sample value.

The EFA analysis extracted six distinct factors, explaining $61.80 \%$ of the total variance for Jordanian universities. Compensation system possessed nine items which showed loading range from 0.764 to 0.899 and explained $17.67 \%$ of the total variance. Out of 19 items in the OCB construct, eight items showed poor loading and thus were removed from the scale. The items loaded between 0.620 and 0.860 and the construct explained $13.88 \%$ of the total variance. The construct of PA had eight items and two of them were deleted, which resulted in six items that loaded between 0.524 and 0.930 and explained $10.08 \%$ of the total variance. The OC had 10 items, five of which were deleted, thus resulting in five items loaded between 0.755 and 0.835 which explained $7.69 \%$ of the total variance. The original construct of the TD had nine items, and three of them were deleted, 
with the remaining six items loaded between 0.682 and 0.823 and explained $7.09 \%$ of the total variance. The RS had 10 items and five were deleted, which resulted in five items loaded from 0.666 to 0.789 and explained $5.39 \%$ of the total variance. Table 2 summarises the EFA result.

To ensure the unidimensionality of identifying constructs, the existence of a single dimension underlying the set of measures confirmatory factor analysis (CFA) was used. For this purpose, Analysis of Moment Structures version 24 (SPSS Amos v24) was used. The researchers examined the validity of this study through the convergent validity test. Awang (2012) and Hair et al. (2014) suggested that convergent validity can be analysed through factor loading. According to Awang (2012), average variance extracted (AVE) should be 0.5 or higher to achieve the validity and composite reliability (CR) should be $\geq 0.6$. Table 3 summarises CFA result and shows that all constructs are reliable and meet the validity criteria.

Moreover, according to Kaynak (2003), chi-square minimum/ degree of freedom $(\mathrm{CMIN} / d f)$, comparative fit index (CFI), normative fit index (NFI), incremental fit index (IFI), root mean square error of approximation (RMSEA) and standardised root mean square residual (SRMR) are the six indicators of the goodness of the model fit, as shown in Table 4. The CMIN/ $d f$ value for the present study was 2.020; this value fully meets the less than three requirements of Bagozzi and Yi (1988). Similarly, CFI, NFI and IFI values

TABLE 2: Exploratory factor analysis result.

\begin{tabular}{lcccc}
\hline Factors & Items & $\begin{array}{c}\text { Factor } \\
\text { loading }\end{array}$ & $\begin{array}{c}\text { Cronbach's } \\
\text { alpha }\end{array}$ & $\begin{array}{c}\text { Variance } \\
\text { explained (\%) }\end{array}$ \\
\hline $\begin{array}{l}\text { Compensation system } \\
\text { (factor 1) }\end{array}$ & 9 & $0.764-0.899$ & 0.946 & 17.67 \\
$\begin{array}{l}\text { Organisational citizenship } \\
\text { behaviour (factor 2) }\end{array}$ & 11 & $0.620-0.860$ & 0.912 & 13.88 \\
$\begin{array}{l}\text { Performance appraisal } \\
\text { (factor 3) }\end{array}$ & 6 & $0.524-0.930$ & 0.844 & 10.08 \\
$\begin{array}{l}\text { Organisational commitment } \\
\text { (factor 4) }\end{array}$ & 5 & $0.755-0.835$ & 0.862 & 7.69 \\
$\begin{array}{l}\text { Training and development } \\
\text { (factor 5) }\end{array}$ & 6 & $0.682-0.823$ & 0.842 & 7.09 \\
$\begin{array}{l}\text { Recruitment and selection } \\
\text { (factor 6) }\end{array}$ & 5 & $0.666-0.789$ & 0.789 & 5.39 \\
\hline Total & $\mathbf{4 2}$ & - & $\mathbf{0 . 8 3 6}$ & $\mathbf{6 1 . 8 0}$ \\
\hline
\end{tabular}

TABLE 3: Confirmatory factor analysis result.

\begin{tabular}{lcccc}
\hline Construct & Items & Factor loading & CR & AVE \\
\hline Compensation system & 9 & $0.575-0.938$ & 0.941 & 0.65 \\
Organisational citizenship behaviour & 11 & $0.647-0.938$ & 0.944 & 0.61 \\
Performance appraisal & 6 & $0.587-0.949$ & 0.891 & 0.59 \\
Organisational commitment & 5 & $0.684-0.943$ & 0.894 & 0.63 \\
Training and development & 6 & $0.581-0.828$ & 0.869 & 0.53 \\
Recruitment and selection & 5 & $0.634-0.796$ & 0.843 & 0.52 \\
\hline
\end{tabular}

$\mathrm{AVE}$, average variance extracted; $\mathrm{CR}$, composite reliability. were found to be $0.943,0.894$ and 0.943 , respectively. All these indicator values were close to 0.9 and fulfil Bentler and Bonett (1980), Byrne (1989) and Hu and Bentler (1998) requirements. Moreover, the SRMR value was 0.077 and the RMSEA value was 0.054 ; these values also meet the benchmark values by Browne and Cudeck (1992) and $\mathrm{Hu}$ and Bentler (1998). Considering the results of these fit indicators, it can be said that the model adequately fits the data.

\section{Mean scores of the study variables}

Table 5 shows the mean scores of the study variables. The respondents' mean score was 2.87 for OC and 2.65 for OCB. These scores indicate that employees' perceptions of their OC and OCB were low. The respondents' mean scores for HRM practices (overall) as well as each of its dimensions were all above the 3.00 mid-point score. These scores indicate that the employees' perceptions of the HRM practices carried out by their organisation are satisfactory.

The results of the correlation analysis which indicates that all the seven constructs were positively correlated with each other with 0.01 significance value are shown in Table 6 . The correlation coefficient between RS and OC $(R=0.763, p=0.01)$ and also with OCB $(R=0.810, p=0.01)$ in Jordanian universities is indicated to be a significant and high positive correlation amongst all HRM practices. The relationship between HRM practices and OC $(R=0.450, p=0.01)$ and also with OCB $(R=0.460, p=0.01)$ is considered to be a significant

TABLE 5: Mean scores of the study variables.

\begin{tabular}{lccc}
\hline Variable & $\begin{array}{c}\text { Number of } \\
\text { items }\end{array}$ & Means & $\begin{array}{c}\text { Standard } \\
\text { deviation }\end{array}$ \\
\hline HRM practices & 26 & 3.97 & 1.01 \\
Recruitment and selection & 5 & 3.66 & 1.00 \\
Compensations system & 9 & 3.85 & 1.12 \\
Training and development & 6 & 4.39 & 0.76 \\
Performance appraisal & 6 & 3.94 & 0.91 \\
Organisational commitment & 5 & 2.87 & 1.50 \\
Organisational citizenship behaviour & 11 & 2.65 & 1.17 \\
\hline
\end{tabular}

HRM, Human resources management.

TABLE 6: Correlation between variables.

\begin{tabular}{lccccccc}
\hline Variable & HRM & RS & CS & TD & PA & OC & OCB \\
\hline HRM & 1 & - & - & - & - & - & - \\
RS & $0.651 * *$ & 1 & - & - & - & - & - \\
CS & $0.577 * *$ & $0.770 * *$ & 1 & - & - & - & - \\
TD & $0.140^{* *}$ & $0.210^{* *}$ & $0.187 * *$ & 1 & - & - & - \\
PA & $0.425 * *$ & $0.686 * *$ & $0.772 * *$ & $0.116 * *$ & 1 & - & - \\
OC & $0.450^{* *}$ & $0.763 * *$ & $0.749 * *$ & $0.134 * *$ & $0.752 * *$ & 1 & - \\
OCB & $0.460 * *$ & $0.810^{* *}$ & $0.765 * *$ & $0.206 * *$ & $0.737 * *$ & $0.923 * *$ & 1 \\
\hline
\end{tabular}

HRM, human resources management; RS, recruitment and selection; CS, compensation system; TD, training and development; PA, performance appraisal; OC, organisational commitment; $\mathrm{OCB}$, organisational citizenship behaviour.

**, Significant at the 0.01 level (two-tailed), $N=350$.

TABLE 4: Fit indicators for confirmatory factor analysis model.

\begin{tabular}{lccccccccc}
\hline \multicolumn{7}{c}{ Model } \\
\hline CMIN & $d f$ & $p$ & CMIN/df & CFI & NFI & IFI & RMSEA \\
\hline 1462.647 & 724 & 0.000 & 2.020 & 0.943 & 0.894 & 0.943 & 0.054 & 0.077 & SRMR \\
\hline
\end{tabular}

CMIN, chi-square minimum; $d f$, degree of freedom; CMIN/df, chi-square minimum/degree of freedom; CFI, comparative fit index; NFI, normative fit index; IFI, incremental fit index; RMSEA, root mean square error of approximation; SRMR, standardised root mean square residual. 
TABLE 7: Result of hypothesis testing.

\begin{tabular}{|c|c|c|c|c|c|c|c|c|}
\hline Hypothesis & Linkage & $R^{2}$ & $F$-test & $p$ & $T$-test & $p$ & B coefficient & Hypotheses acceptance \\
\hline $\mathrm{H} 1$ & $\mathrm{HRM} \rightarrow \mathrm{OC}$ & 0.2021 & 88.1710 & 0.0000 & 9.3899 & 0.0000 & 0.1073 & Accepted \\
\hline $\mathrm{H} 2$ & $\mathrm{OC} \rightarrow \mathrm{OCB}$ & 0.8523 & 2008.374 & 0.0000 & 44.815 & 0.0000 & 1.648 & Accepted \\
\hline H3a & $\mathrm{HRM} \rightarrow \mathrm{OC} \rightarrow \mathrm{OCB}$ & 0.8548 & 1021.4577 & 0.0000 & 2.4400 & 0.0125 & 0.0238 & Accepted \\
\hline $\mathrm{H} 3 \mathrm{~b}$ & $\mathrm{RS} \rightarrow \mathrm{OC} \rightarrow \mathrm{OCB}$ & 0.8793 & 1264.2472 & 0.0000 & 8.8128 & 0.0000 & 0.3029 & Accepted \\
\hline $\mathrm{H} 3 \mathrm{c}$ & $\mathrm{CS} \rightarrow \mathrm{OC} \rightarrow \mathrm{OCB}$ & 0.8646 & 1108.0463 & 0.0000 & 5.6151 & 0.0000 & 0.2586 & Accepted \\
\hline H3d & $\mathrm{TD} \rightarrow \mathrm{OC} \rightarrow \mathrm{OCB}$ & 0.8592 & 1059.1477 & 0.0000 & 4.1335 & 0.0000 & 0.1884 & Accepted \\
\hline $\mathrm{H} 3 \mathrm{e}$ & $\mathrm{PA} \rightarrow \mathrm{OC} \rightarrow \mathrm{OCB}$ & 0.8565 & 1035.7918 & 0.0000 & 3.1918 & 0.0015 & 0.1992 & Accepted \\
\hline
\end{tabular}

HRM, human resources management; RS, recruitment and selection; CS, compensation system; TD, training and development; PA, performance appraisal; OC, organisational commitment; $\mathrm{OCB}$, organisational citizenship behaviour.

and low positive correlation. The relationship between CS and OCB is considered to be a high positive correlation $(R=0.765, p=0.01)$ and the relationship between PA and OCB is considered to be a high positive correlation $(R=0.737$, $p=0.01)$. However, the relationship between TD and OCB indicated to be very weak positive correlation $(R=0.206$, $p=0.01)$. The correlation coefficient of OC is indicated as the highest level of positive correlation with OCB and is considered to be a very high positive correlation $(R=0.923$, $p=0.01)$.

\section{Hypotheses testing}

The researchers used the PROCESS macro for SPSS Version 3.1 to test the study hypotheses, which is a software developed to help researchers to test the relationships between variables that have a mediator or moderator (Hayes, 2018). Table 7 summarises the details of principle and subhypotheses. According to Moore, Notz and Fligner's (2013) criteria, the results of this study showed that H1 (human resource management practices positively influence $O C$ ) indicated that HRM practices have a weak impact on OC $\left(R^{2}=0.2021, p=0.000\right)$. Hypothesis 2 (OC positively influences $\mathrm{OCB})$ indicated that $\mathrm{OC}$ has demonstrated a significant and positive impact on OCB $\left(R^{2}=0.852, p=0.000\right)$. Likewise, H3a (OC mediates the relationship between human resource management practices and $\mathrm{OCB}$ ) indicated that $\mathrm{OC}$ has mediated the relationship between HRM practices and OCB and has a strong and positive impact $\left(R^{2}=0.8548, p=0.0125\right)$. Hypotheses 3b, 3c, 3d and 3e indicated that OC has also mediated the relationship between RS, CS, TD and PA, and OCB and has a strong and positive impact $\left(R^{2}=0.8793\right.$, $0.8646,0.8592$ and $0.8565, p=0.000,0.000,0.000$ and 0.0015 ), respectively. Therefore, the hypotheses and sub-hypotheses have yielded statistically significant results and are accepted.

\section{Discussions}

The amount of research about the functions of HRM and its impact on OC and OCB on Jordanian universities is limited. Accordingly, the current study aimed at classifying this issue in the literature by empirically examining the relationship between HRM practices and OCB amongst the administrative staff of Jordanian universities and by determining how an OC mediates this relationship in these universities. The results showed that the relationship between HRM practices and OC is at $20.21 \%$, thus rendering it weak. This implies that university management must abandon the traditional frame of HRM practices. Jordanian universities must give importance to career growth assurance of their employees in their policies and action plans. Human resources management practices must be aimed at maintaining OC. Therefore, Jordanian universities should increase attention towards HRM policies and practices, which in turn will affect the level of OC amongst their administrative staff. Moreover, this study has shown that OC has positive and significant relationship with OCB by $85.23 \%$. This indicates that the Jordanian universities are dependent on increasing the OC of the administrative staff to conduct their operations and achieve a high degree of OCB. This can be attained by providing effective training for staff in order to increase their skills in dealing with work-related issues, to empower them to design and examine their work, and to further their education and self-improvement. This training will lead to improvements in employees' performance within the organisation. Therefore, the staff who have a strong commitment towards the organisation will generally demonstrate a positive OCB amongst their colleagues (Chang, Nguyen, Cheng, Kuo, \& Lee, 2016; Farndale et al., 2011; Mowday, Porter, \& Steers, 2013).

The results of this study demonstrate that OC has a significant impact on and mediates the relationship between the HRM practices and OCB by $85.48 \%$. This implies that OC plays a significant role in enhancing the relationship between HRM practices and OCB. It is important for Jordanian universities to comprehend all pertinent requirements for successful implementation of strategies and must give due consideration to the implementation requirements of the chosen strategy to increase the efficiency of OCB work. Jordanian universities have the ability to spearhead strategic implementation process and implement HRM practices. The development of strategic goals, establishing a connection between the motivation and structure of rewards that enable to accomplish the outcome and creating policies as well as procedures for the appropriate usage of strategic implementation are vital issues for Jordanian universities (Al Adresi \& Darun, 2017; Allui \& Sahni, 2016; Matsuyama, 2006; Mesilhy \& Ismail, 2018).

Furthermore, the analysis of the results shows that the OC mediated the relationship between RS and OCB by $87.93 \%$, which is known to have the highest impact of all HRM practices. This reveals that OC plays an important role in affecting the relationship between RS and OCB. 
This also suggests that Jordanian universities are providing employment tests which explain and describe how the work is performed and what policies and procedures are followed by the university. This, in turn, indicates that clearing these tests and interviews gives the applicant a stronger sense of affiliation towards the university and leads to higher levels of OC and OCB (Kehoe \& Wright, 2013; Lamba \& Choudhary, 2013; Sareen, 2018).

Organisational commitment mediates the relationship between CS and OCB by $86.46 \%$. This indicates that the role of OC significantly impacts the relationship between CS and OCB. Therefore, Jordanian universities are committed to implement compensation and rewards policy. Because $\mathrm{OC}$ is largely related to the compensation awarded by university, Jordanian universities must develop clear strategies and match the amount of effort provided by the staff as well as linking seniority with promotion and taking into account the level of staff performance to increase the level of OC and OCB (Fiorito, Bozeman, Young, \& Meurs, 2007; Gope, Elia, \& Passiante, 2018; Suryani et al., 2019). Likewise, OC mediates the link between TD and OCB by $85.92 \%$. This indicates that OC has a significant role in influencing the relationship between TD and OCB. This suggests that Jordanian universities can increase the level of OC and OCB of their administrative staff by investing more in TD of their staff and giving them sufficient opportunities to improve themselves. Thus, TD allows the administrative staff to acquire new skills, improve their self-confidence and overall increase their OC and enhance their OCB. Training programmes aimed at developing relationships between colleagues or supervisors as well as subordinates are expected to increase the level of OC and OCB within universities. Therefore, universities should focus on TD programmes that aim to achieve positive attitudes and behaviours of staff and thus increase their OC to their work and university (Aguinis \& Kraiger, 2009; Rubel \& Rahman, 2018; Shakya, 2018).

Finally, OC mediates the relationship between the PA and OCB by $85.65 \%$. A conceivable explanation behind this finding might be that the purpose of the PA is to assist the university in judging the accuracy of the policies and programmes it adopts, whether it is the policies of RS, TD programmes or HR procedures. Also, it helps staff to develop their strengths, address their weaknesses and create a sense of trust in the seriousness of the university in which they work, thereby increasing their OC to their university and their work. These enhancements are necessary for operations in Jordanian universities, as the working conditions are more competitive there than other universities. In doing so, the demands of career development related to enhancing the personal skills of staff will be met, and the claims for basic belief and values such as the enhancement of individual abilities and professional advancement, all of which improve their OC, will be validated. Therefore, the results show that OC plays an important role in enhancing the relationship between PA and OCB (Allui \& Sahni, 2016; Fletcher, 2001; Husin, Chelladurai, \& Musa, 2012; Neha \& Himanshu, 2015; Poursafar, Rajaeepour, Seyadat, \& Oreizi, 2014).

\section{Conclusion}

The existence of an organisation depends on the contribution of significant elements of HRM practices. Organisational citizenship behaviour in a university has more importance than any other division because administrative staff members have direct and constant contact with the students and university staff they serve. Administrative staff behaviour can ultimately improve or reduce the performance of the university. To meet or exceed what is required from them, service-oriented staff must adjust their work behaviours to address the unique nature of the needs they fulfil and must identify the vital role of OCB in universities. Jordanian universities must develop a suitable environment to lead HRM procedures to prompt OCB and increase their OC. The results of this study indicate that the OC derived from HRM practices is a critical and fundamental variable that can be used by Jordanian universities. Therefore, it works to facilitate the positive behaviour of administrative staff and enhance the OCB towards their organisation, which in turn will have a positive impact of HRM practices on OCB. Regarding practical and managerial implications, the main findings suggest that Jordanian universities will benefit if HRM practices are strengthened and become more reliable, as this may increase the confidence of administrative staff in the organisation and consequently lead to a higher level of OC. As a result, administrative staff may be more likely to make additional and voluntary efforts in their work when they have a high level of OC.

There are some limitations and opportunities for future studies. Firstly, the data for the present study were collected from only Jordanian universities; therefore, it is not clear whether the relationship between HRM practices, OC and OCB is the same in other countries. Secondly, there is a possibility of bias in the conventional method of answering all questions. Although the researchers did not statistically find the problems of the method prevalent in this study, they cannot be excluded entirely. Thirdly, this study focused only on Jordanian universities, which raises the question as to whether the relationships that examined in this study will be different for other sectors.

\section{Acknowledgements}

This study is based on the first author's (L.T.)doctorate degree dissertation entitled 'The functions of strategic human resource management and their impact on organisational commitment and organisational citizenship behaviour in Jordanian universities', which will be submitted to Near East University. The co-author of this study (S.Z.E.) is the supervisor of the dissertation.

\section{Competing interests}

The authors declare that no competing interest exists.

\section{Authors' contributions}

L.T. and S.Z.E. have contributed equally to the planning, researching, structuring and writing of this study. 


\section{Funding information}

This research received no specific grant from any funding agency in the public, commercial or not-for-profit sectors.

\section{Data availability statement}

Data sharing is not applicable to this article as no new data were created or analysed in this study.

\section{Disclaimer}

The authors hereby declare that this study is their own original work and has not been published or under consideration for publication elsewhere.

\section{Reference}

Aguinis, H., \& Kraiger, K. (2009). Benefits of training and development for individuals and teams, organizations, and society. Annual Review of Psychology, 60(1) 451-474. https://doi.org/10.1146/annurev.psych.60.110707.163505

Ahmad, K.Z. (2011). The association between training and organizational citizenship behavior in the digital world. Communications of the IBIMA, 11(1), 1-11. https:// doi.org/10.5171/2011.448699

Al-Mzary, M., Al-rifai, A.D., \& Al-Momany, M. (2015). Training and its impact on the performance of employees at Jordanian universities from the perspective of employees: The case of Yarmouk University. Journal of Education and Practice, 6(32), 128-140.

Al-Saudi, M. (2012). The impact of organizational climate upon the innovative behavior at Jordanian private universities as perceived by employees: A field study. International Business and Management, 5(2), 14-26.

Al Adresi, A., \& Darun, M.R. (2017). Determining relationship between strategic human resource management practices and organizational commitment. International Journal of Engineering Business Management, 9(1), 1-9. https://doi. org/10.1177/1847979017731669

Allui, A., \& Sahni, J. (2016). Strategic human resource management in higher education institutions: Empirical evidence from Saudi. Procedia - Social and Behavioral Sciences, 235(1), 361-371. https://doi.org/10.1016/j.sbspro.2016. 11.044

Alvi, A.K., Zarish, H.M., \& Bilal, R. (2016). The impact of employee training on commitment and OCB: Evidence from FMCGs in Lahore, Pakistan. Gomal University Journal of Research, 1(1), 105-115.

Angelina, A., \& Subudi, M. (2014). The impact of financial compensation and leadership style on employee satisfaction and organizational citizenship behavior (OCB) in Alit's beach Bali hotel. E-Journal Management University of Udayana, 3(4), 1035-1049.

Atteya, N.M. (2012). Testing the impact of the human resource management practices on job performance: An empirical study in the Egyptian joint venture petroleum companies Nermine Magdy Atteya visiting scholar State University of New York at Oswego Department of Marketing. International Journal of Business and Social Oswego Department of
Science, 3(9), 105-120.

Awang, Z. (2012). SEM structural equation modeling using AMOS graphic. Shah Alam: Universiti Teknologi MARA Publication Centre (UPENA).

Bagozzi, R.P., \& Yi, Y. (1988). On the evaluation of structural equation models. Journal of the Academy of Marketing Science, 16(1), 74-94. https://doi.org/10.1007/ BF02723327

Bartlett, K.R., \& Kang, D.S. (2004). Training and organizational commitment among nurses following industry and organizational change in New Zealand and the United States. Human Resource Development International, 7(4), 423-440. https://doi.org/10.1080/1367886042000299799

Bentler, P.M., \& Bonett, D.G. (1980). Significance tests and goodness of fit in the analysis of covariance structures. Psychological Bulletin, 88(3), 588-606. https:// doi.org/10.1037/0033-2909.88.3.588

Bettencourt, L.A., Gwinner, K.P., \& Meuter, M.L. (2001). A comparison of attitude personality, and knowledge predictors of service-oriented organizational citizenship behaviors. Journal of Applied Psychology, 86(1), 29-41. https://doi. org/10.1037/0021-9010.86.1.29

Bratton, J., \& Gold, J. (2017). Human resource management: Theory \& practice (6th edn.). London: Palgrave Macmillan.

Browne, M.W., \& Cudeck, R. (1992). Alternative ways of assessing model fit Sociological Methods \& Research, 21(2), 230-258. https://doi.org/10.1177/ 0049124192021002005

Byrne, B.M. (1989). A primer of LISREL: Basic applications and programming for confirmatory factor analytic models. New York, NY: Springer-Verlag.

Chang, K., Nguyen, B., Cheng, K.-T., Kuo, C.-C., \& Lee, I. (2016). HR practice, organisational commitment and citizenship behaviour: A study of primary schoo teachers in Taiwan. Employee Relations: The International Journal, 38(6), 1-45. https://doi.org/10.1108/ER-12-2015-0218
Cho, S., Woods, R.H., Jang, S. (Shawn), \& Erdem, M. (2006). Measuring the impact of human resource management practices on hospitality firms' performances. International Journal of Hospitality Management, 25(2), 262-277. https://doi. org/10.1016/j.ijhm.2005.04.001

Claudia, M. (2018). The influence of perceived organizational support, job satisfaction and organizational commitment toward organizational citizenship behavior. Journal of Indonesian Economy and Business, 33(1), 23-45. https://doi.org/ 10.22146/jieb.17761

Danendra, A.A.N.B., \& Mujiati, N.W. (2016). The effect of motivation, compensation, and organizational commitment to organizational citizenship behavior. E-Journal Management University of Udayana, 5(10), 6229-6259.

Deadrick, D.L., \& Stone, D.L. (2014). Human resource management: Past, present, and future. Human Resource Management Review, 24(3), 193-195. https://doi.org/ 10.1016/j.hrmr.2014.03.002

Dockel, A., Basson, J.S., \& Coetzee, M. (2012). The effect of retention factors on organisational commitment: An investigation of high technology employees. SA Journal of Human Resource Management, 4(2), 20-28. https://doi.org/10.4102/ sajhrm.v4i2.91

Dysvik, A., \& Kuvaas, B. (2008). The relationship between perceived training opportunities, work motivation and employee outcomes. International Journal of Training and Development, 12(3), 138-157. https://doi.org/10.1111/j.1468-2419. 2008.00301.x

Farndale, E., Hope-Hailey, V., \& Kelliher, C. (2011). High commitment performance management: The roles of justice and trust. Personnel Review, 40(1), 5-23. https://doi.org/10.1108/00483481111095492

Fiorito, J., Bozeman, D.P., Young, A., \& Meurs, J.A. (2007). Organizational commitment, human resource practices, and organizational characteristics. Journal of Managerial Issues, 19(2), 186-207.

Fletcher, C. (2001). Performance appraisal and management: The developing research agenda. Journal of Occupational and Organizational Psychology, 74(1), 473-487. https://doi.org/10.1348/096317901167488

Friedman, A., Carmeli, A., \& Dutton, J.E. (2018). When does respectful engagement with one's supervisor foster help-seeking behaviors and performance? Journal of Vocational Behavior, 104, 184-198. https://doi.org/10.1016/j. jvb.2017.11.007

Gope, S., Elia, G., \& Passiante, G. (2018). The effect of HRM practices on knowledge management capacity: A comparative study in Indian IT industry. Journal of Knowledge Management, 22(3), 649-677. https://doi.org/10.1108/JKM-102017-0453

Graso, M., Camps, J., Strah, N., \& Brebels, L. (2019). Organizational justice enactment: An agent-focused review and path forward. Journal of Vocational Behavior 10(16), 1-23

Grawe, S.J., Daugherty, P.J., \& McElroy, J.C. (2012). External organizational commitment among organizational implants: The case of logistics service providers. Transportation Research Part E: Logistics and Transportation Review, 48(1), 165-177. https://doi.org/10.1016/j.tre.2011.08.002

Guyo, A.G. (2015). Role of human resource management in development of organizational citizenship behaviour among the civil servants in Kenya. Unpublished Phd thesis. Juja: Jomo Kenyatta University of Agriculture and Technology.

Hai, L., \& Mian, Z. (2007). The relationship between performance appraisal and organizational citizenship behavior: The mediating role of organizational commitment. In International conference on wireless communications, networking and mobile computing, WiCOM 2007 (pp. 6483-6486). Shanghai, China: IEEE.

Hair, J.F., Black, W.C., Babin, B.J., \& Anderson, R.E. (2014). Multivariate data analysis (7th edn.). Harlow: Pearson Education Limited.

Hartono, M.F.E., \& Handayani, R. (2019). The effects of job satisfaction and organizational commitment on organizational citizenship behavior. In S. Kusmana, I. Rosnidah, A.G. Abdullah, H. Budiana, \& S. Khumayah (Eds.), International symposium on social sciences, education, and humanities (ISSEH 2018) (Vol. 306, pp. 201-205). Cirebon: Atlantis Press.

Hassan, S., \& Mahmood, B. (2016). Relationship between HRM practices and organizational commitment of employees: An empirical study of textile sector in Pakistan. International Journal of Academic Research in Accounting, Finance and Management Sciences, 6(1), 23-28. https://doi.org/10.6007/IJARAFMS/v6i1/1952

Hayes, A.F. (2018). Introduction to mediation, moderation, and conditional process analysis: A regression-based approach (2nd edn.). New York, NY: The Guilford Press.

Hinkin, T.R. (1998). A brief tutorial on the development of measures for use in survey questionnaires. Organizational Research Methods, 2(1), 104-121. https://doi. org/10.1177/109442819800100106

Holeche, L. (2017). The future of HR. In G. Rees \& P.E. Smith (Eds.), Strategic human resource management: An international perspective (2nd edn., pp. 532-572) London: Sage.

Hoon, L.S., \& Heard, A. (2000). A managerial perspective of the objectives of HRM practices in Singapore: An exploratory study. Singapore Management Review, 22(1), 65-82.

Hu, L., \& Bentler, P.M. (1998). Fit indices in covariance structure modeling: Sensitivity to underparameterized model misspecification. Psychological Methods, 3(4), 424-453. https://doi.org/10.1037/1082-989X.3.4.424

Huang, T.C. (2001). The effects of linkage between business and human resource management strategies. Personnel Review, 30(2), 132-151. https://doi.org/ 10.1108/00483480110380316 
Husin, S., Chelladurai, P., \& Musa, G. (2012). HRM practices, organizational citizenship behaviors, and perceived service quality in golf courses. Journal of Sport Management, 26(2), 143-158. https://doi.org/10.1123/jsm.26.2.143

Ismail, R.M.A. (2018). Performance implication of the relationship between competitive strategy and SHRM practices on employee outcomes in Saudi Banks a field study. International Journal of Business and Social Science, 9(2), 64-75.

Jaros, S.J. (1997). An assessment of Meyer and Allen's (1991) three-component model of organizational commitment and turnover intentions. Journal of Vocational Behavior, 51(3), 319-337. https://doi.org/10.1006/jvbe.1995.1553

Jawahar, I.M. (2006). Correlates of satisfaction with performance appraisal feedback. Journal of Labor Research, 27(2), 213-236. https://doi.org/10.1007/s12122-0061004-1

Kaiser, H.F. (1974). An index of factorial simplicity. Psychometrika, 39(1), 31-36. https://doi.org/10.1007/BF02291575

Kaynak, H. (2003). The relationship between total quality management practices and their effects on firm performance. Journal of Operations Management, 21(4), 405-435. https://doi.org/10.1016/S0272-6963(03)00004-4

Kehoe, R.R., \& Wright, P.M. (2013). The impact of high-performance human resource practices on employees' attitudes and behaviors. Journal of Management, 39(2), 366-391. https://doi.org/10.1177/0149206310365901

Khatri, N. (2000). Managing human resource for competitive advantage: A study of companies in Singapore. International Journal of Human Resource Management, 11(2), 336-365. https://doi.org/10.1080/095851900339909

Kuehn, K.W., \& Al-Busaidi, Y. (2002). Citizenship behavior in a non-western context: An examination of the role of satisfaction, commitment and job characteristics on self-reported OCB. International Journal of Logistics Management, 12(2), 107-125. https://doi.org/10.1108/eb047446

Küskü, F. (2003). Employee satisfaction in higher education: The case of academic and administrative staff in Turkey. Career Development International, 8(7), 347-356. https://doi.org/10.1108/13620430310505304

Lamba, S., \& Choudhary, N. (2013). Impact of HRM practices on organizational commitment of employees. International Journal of Advancements in Research \& Technology, 2(4), 407-423.

Liao, Y.S. (2005). Business strategy and performance: The role of human resource management control. Personnel Review, 34(3), 294-309. https://doi.org/10.1108/ 00483480510591444

Liu, C.-M. (2006). The early employment influences of sales representatives on the development of organizational commitment. Employee Relations, 29(1), 5-15. development of organizational commitment.
https://doi.org/10.1108/01425450710714441

Liu, Y., Loi, R., \& Ngo, H.-Y. (2018). Linking organizational social exchange to intention to leave: Does normative commitment matter? International Journal of Human Resource Management, 5192(1), 1-21. https://doi.org/10.1080/09585192.2017. Resource
1423097

MacKenzie, S.B., Podsakoff, P.M., \& Ahearne, M. (2006). Some possible antecedents and consequences of in-role and extra-role salesperson performance. Journal of Marketing, 62(3), 87. https://doi.org/10.1177/002224299806200306

Makau, M.M., Nzulwa, J., \& Wabala, S.W. (2017). Influence of compensation programs on organisational citizenship behaviour among employees of Kenya Women Microfinance Bank Limited. The Strategic Journal of Business \& Change Management, 4(32), 587-604.

Matsuyama, K. (2006). Employee's acceptance of new HRM practices and organizational commitment: A case of university. Japanese Journal of Administrative Science, 19(3), 251-261. https://doi.org/10.5651/jaas.19.251

Meyer, J.P., Stanley, D.J., Herscovitch, L., \& Topolnytsky, L. (2002). Affective, continuance, and normative commitment to the organization: A meta-analysis of antecedents, correlates, and consequences. Journal of Vocational Behavior, 61(1) 20-52. https://doi.org/10.1006/jvbe.2001.1842

Millmore, M., Lewis, P., Saunders, M., Thornhill, A., \& Morrow, T. (2007). Strategic human resource management: Contemporary issues. Harlow: Financial Time Prentice Hall.

Moore, D.S., Notz, W.I., \& Fligner, M.A. (2013). The basic practice of statistics (6th edn.). New York, NY: W. H. Freeman and Company.

Morrison, E.W. (1996). Organizational citizenship behavior as a critical link between HRM practices and service quality. Human Resource Management, 35(4), 493-512. hRM practices and service quality. Human Resource Management, 35(4), 493-512. https://doi.org/
3E3.0.CO;2-R

Mowday, R.T., Porter, L.W., \& Steers, R.M. (2013). Employee-organization linkages: The psychology of commitment, absenteeism, and turnover. New York, NY: Academic psychol
Press.

Nasurdin, A.M., Hemdi, M.A., \& Lye, P.G. (2008). Does perceived organizational support mediate the relationship between human resource management practices and organizational commitment. Asian Academy of Management Journal, 13(1), 15-36.

Neha, S., \& Himanshu, R. (2015). Impact of performance appraisal on organizational commitment and job satisfaction. International Journal of Engineering and Management Sciences, 6(2), 95-104.

Noor, A. (2009). Examining organizational citizenship behavior as the outcome of organizational commitment: A study of universities' teachers of Pakistan. Army Public College of Management Sciences, 2(1), 1-23.

Norris-Watts, C., \& Levy, P.E. (2004). The mediating role of affective commitment in the relation of the feedback environment to work outcomes. Journal of Vocational Behavior, 65(3), 351-365. https://doi.org/10.1016/j.jvb.2003.08.003

Organ, D.W. (1990). The motivational basis of organizational citizenship behavior. Research in Organizational Behavior, 12(1), 43-72.
Organ, D.W., Podsakoff, P.M., \& MacKenzie, S.B. (2006). Organizational citizenship behavior: Its nature, antecedents, and consequences. Thousand Oaks, CA: Sage.

Park, R., \& Searcy, D. (2012). Job autonomy as a predictor of mental well-being: The Psychology, 27(3), 305-316. https://doi.org/10.1007/s10869-011-9244-3

Paul, A.K., \& Anantharaman, R.N. (2004). Influence of HRM practices on organizational commitment: A study among software professionals in India. Human Resource Development Quarterly, 15(1), 77-88. https://doi.org/10.1002/hrdq.1088

Payne, S.C., \& Huffman, A.H. (2005). A longitudinal examination of the influence of mentoring on organizational commitment and turnover. Academy of Management Journal, 48(1), 158-168. https://doi.org/10.5465/amj.2005.15993166

Pettijohn, C.E., Pettijohn, L.S., \& D’Amico, M. (2001). Characteristics of performance appraisals and their impact on sales force satisfaction. Human Resource Development Quarterly, 12(2), 127-146. https://doi.org/10.1002/hrdq.4

Porter, L.W., Steers, R.M., Mowday, R.T., \& Boulian, P.V. (1974). Organizational commitment, job satisfactions and turnover among psychiatric technicians. Journal of Applied Psychology, 59(5), 603-609. https://doi.org/10.1037/h0037335

Poursafar, A., Rajaeepour, S., Seyadat, S.A., \& Oreizi, H.R. (2014). Developmental performance appraisal and organizational citizenship behavior: Testing a mediation model. Journal of Education and Practice, 5(16), 184-194.

Qawasmeh, F.M. (2018). Assessment of organizational citizenship behavior (OCB) in Jordanian universities. International Journal of Academic Research in Business and Social Sciences, 8(12), 68-82. https://doi.org/10.6007/IJARBSS/v8-i12/4991

Roos, G., Fernstroom, L., \& Pike, S. (2004). Human resource management and business performance measurement. Measuring Business Excellence, 8(1), 28-37. https:// doi.org/10.1108/13683040410524711

Rubel, M., \& Rahman, M.H.A. (2018). Effect of training and development on organizational citizenship behavior (OCB): An evidence from private commercial banks in Bangladesh. Global Journal of Management and Business Research: A Administration and Management, 18(8), 1-11.

Saraih, U.N., Aris, A.Z.B.Z., Mohd Karim, K., Abu-Samah, I.H., Sa'aban, S., \& Suhana, A.M. (2017). Relationships between organizational commitment, OCB, organizational justice and turnover intention: Evidence from educational institution in Malaysia. Review of Integrative Business and Economics Research, 6(2), 64-77.

Sareen, B. (2018). Relationship between strategic human resource management and job satisfaction. International Journal of Current Research in Life Sciences, 7(3), 1229-1233

Savaneviciene, A., \& Stankeviciute, Z. (2011). Human resource management practices linkage with organizational commitment and job satisfaction. Economics and Management, 16, 921-928.

Schappe, S.P. (1998). The influence of job satisfaction, organizational commitment, and fairness perceptions on organizational citizenship behaviors. Journal of Psychology, 132(3), 277-290. https://doi.org/10.1080/00223989809599167

Scholl, R.W. (1981). Differentiating organizational commitment from expectancy as a motivating force. Academy of Management Review, 6(4), 589-599. https://doi. org/10.5465/amr.1981.4285698

Sekaran, U., \& Bougie, R. (2016). Research methods for business: A skill-building approach (7th edn.). Chichester: Wiley \& Sons Ltd.

Shakya, A. (2018). Human resource management practices in higher education in U. P. Multidisciplinary Higher Education, Research, Dynamics \& Concepts: Opportunities \& Challenges for Sustainable Development, 1(1), 123-125.

Sial, M.A., Jilani, S.M.A., Imran, R., \& Zaheer, A. (2011). Effect of human resource practices on organizational commitment in Pakistani universities. World Applied Sciences Journal, 15(6), 793-798.

Stamper, C.L., \& Dyne, L. Van. (2014). Work status and organizational citizenship behavior: A field study of restaurant employees. Journal of Organizational Behavior, 22(5), 517-536. https://doi.org/10.1002/job.100

Suifan, T.S. (2015). The effect of human resources practices on organizational commitment: A Jordanian study. Journal of Management Research, 7(4), 222 https://doi.org/10.5296/jmr.v7i4.7972

Sung, S.Y., \& Choi, J.N. (2014). Multiple dimensions of human resource development and organizational performance. Journal of Organizational Behavior, 35(6), 851-870. https://doi.org/10.1002/hrm.21765

Sung, S.Y., Choi, J.N., \& Kang, S.-C. (2017). Incentive pay and firm performance: Moderating roles of procedural justice climate and environmental turbulence Human Resource Management, 56(2), 287-305. https://doi.org/10.1002/hrm.21765

Suparjo, S., \& Darmanto, S. (2015). Mediating role of jobs satisfaction among organizational commitment, organizational culture and organizational citizenship behavior (OCB): Empirical study on private higher education in central Java, Indonesia. Journal of Research in Marketing, 4(1), 289-296. https://doi.org/10.17722/jorm.v4i1.112

Suryani, N.N., Gama, I.G., \& Parwita, G.B.S. (2019). The effect of organizational compensation and commitment to organizational citizenship behavior in the cooperative and small, middle enterprises department of Bali province. International Journal of Contemporary Research and Review, 10(1), 21210-21218. https://doi.org/10.15520/ijcrr.v10i01.643

Tsaur, S.H., \& Lin, Y.C. (2004). Promoting service quality in tourist hotels: The role of HRM practices and service behavior. Tourism Management, 25(4), 471-481. https://doi.org/10.1016/S0261-5177(03)00117-1

Wentland, D. (2003). The strategic training of employees model: Balancing organizational constraints and training content. SAM Advanced Management Journal, 68(1), 56-80. https://doi.org/10.1177/014920630102700502

Whitener, E.M. (2001). Do 'high commitment' human resource practices affect employee commitment? A cross-level analysis using hierarchical linear modelling. Journal of Management, 27(5), 515-535. 
Wiener, Y. (1982). Commitment in organizations: A normative view. Academy of Management Review, 7(3), 418-428. https://doi.org/10.5465/amr.1982 4285349

Wright, P.M., Gardner, T.M., \& Moynihan, L.M. (2003). The impact of HR practices on the performance of business units. Human Resource Management Journal, 13(3), 21-36. https://doi.org/10.1111/j.1748-8583.2003.tb00096.x
Yanti, P.E.T., \& Supartha, I.W.G. (2017). The effect of organizational commitment and job satisfaction on organizational citizenship behavior. E-Journal Management University of Udayana, 6(2), 721-747.

Zheng, W., Zhang, M., \& Li, H. (2012). Performance appraisal process and organizational citizenship behavior. Journal of Managerial Psychology, 27(7), 732-752. https:// doi.org/10.1108/02683941211259548 